THE EFFECT OF RISK BASED BANK RATING WITH RGEC APPROACH TO INCOME GROWTH IN BANKING COMPANIES REGISTERED IN INDONESIA STOCK EXCHANGE 2016-2018

\title{
PENGARUH RISK BASED BANK RATING DENGAN PENDEKATAN RGEC TERHADAP PERTUMBUHAN LABA PADA PERUSAHAAN PERBANKAN YANG TERDAFTAR DI BURSA EFEK INDONESIA 2016-2018
}

\author{
Oleh: \\ Susfayetti' ${ }^{1)}$, Nella Safelia ${ }^{2)}$ \\ ${ }^{1 \& 2)}$ Dosen Fakultas Ekonomi dan Bisnis Universitas Jambi \\ Email: susfayetti@gmail.com, ${ }^{1)}$,nelasafelia@unja.ac.id ${ }^{2)}$
}

\begin{abstract}
This study was to examined and analyzed the effect of Risk profile, GCG, Earning and Capital on Profit growth in Banking Companies listed on the Indonesia Stock Exchange in the 2016-2018 Period? The sample in this study is a banking company listed on the Indonesia Stock Exchange in the period 2016-2018. The analysis technique used in this study is multiple linear regression. The results of this study indicate that Risk Profile, GCG, Earning and Capital have a significant simultaneous effect on Profit Growth in Banking companies. Risk Profile proxied by NPL, Good Corporate Governance (GCG) and Capital proxied by CAR has an effect on Profit Growth, whereas Risk Profile proxied by LDR, Earning proxied by ROA, Earning proxied by BOPO, does not affect Profit Growth in LDR Banking companies listed on the Indonesia Stock Exchange in 2016-2018.
\end{abstract}

Keyword: Profit growth, NPL, LDR, GCG, ROA, BOPO,CAR

\begin{abstract}
ABSTRAK
Penelitian ini bertujuan untuk menguji dan menganalisis pengaruh Risk profile, GCG, Earning dan Capital terhadap pertumbuhan Laba pada Perusahaan Perbankan yang terdaftar di Bursa Efek Indonesia Periode 2016-2018? Sampel pada penelitian ini adalah perusahaan perbankan yang terdaftar di Bursa Efek Indonesia periode tahun 2016-2018. Teknik analisis yang digunakan dalam penelitian ini adalah regresi linear berganda. Hasil penelitian ini menunjukkan bahwa Risk Profile, GCG, Earning dan Capital mempunyai pengaruh signifikan secara simultan terhadap Pertumbuhan Laba pada perusahaan Perbankan. Risk Profile yang diproksikan dengan NPL, Good Corporate Governance ( $G C G)$ dan Capital yang diproksikan dengan CAR berpengaruh terhadap Pertumbuhan Laba, sedangkan Risk Profile yang diproksikan dengan LDR, Earning yang diproksikan dengan ROA, Earning yang diproksikan dengan BOPO, tidak berpengaruh terhadap Pertumbuhan Laba pada perusahaan Perbankan yang terdaftar di Bursa Efek Indonesia tahun 2016-2018.
\end{abstract}

Kata Kunci: Pertumbuhan laba, NPL, LDR, GCG, ROA, BOPO dan CAR 


\section{PENDAHULUAN \\ 1.1. Latar Belakang Penelitian}

Sejalan dengan tren pemulihan ekonomi dunia, ekonomi domestik tumbuh cukup solid yang utamanya ditopang oleh kenaikan investasi dan kinerja perdagangan internasional. Dari sisi perbankan, ketahanan perbankan masih tetap solid ditopang tingginya CAR (tingkat kemampuan pemoalan ) yang didukung dengan membaiknya tingkat efisiensi perbankan. Selain itu, profil risiko perbankan masih terjaga dengan baik tercermin dari risiko kredit yang menurun serta risiko likuiditas dan risiko pasar yang relatif rendah.

Kinerja perusahaan dapat tercermin dengan Tingkat Kesehatan Bank, dimana Untuk menilai kinerja perusahaan perbankan umumnya menggunakan beberapa aspek penilaian. Bank Indonesia mengeluarkan aturan tingkat kesehatan bank tertulis dalam Nomor 13/1/PBI/2011 pasal 2 ayat (3) tentang Penilaian Tingkat Kesehatan Bank Umum menetapkan bank juga wajib melakukan penilaian tingkat kesehatan bank secara individual dengan menggunakan pendekatan risiko (Risk-Based Bank Rating), dengan berbasis RGEC dimana cakupan penilaian terhadap risk profile (profil risiko), good corporate governance (GCG), earnings (rentabilitas), dan capital (permodalan). Berlakunya Peraturan Bank Indonesia tersebut, Peraturan Bank Indonesia Nomor 6/10/PBI/2004 tentang Sistem Penilaian Tingkat Kesehatan Bank Umum dicabut dan dinyatakan tidak berlaku sejak Januari 2012 (Peraturan Bank Indonesia Nomor 13/1/PBI/2011). Tujuan penilaian tersebut untuk mengetahui kondisi bank yang sesungguhnya apakah bank tersebut dalam keadaan sehat atau kurang sehat atau tidak sehat dilihat dari pertumbuhan laba perusahaanya. Jika kondisinya dalam keadaan tidak sehat maka, perlu segera untuk diambil tindakan.

Risk Based Bank Rating (RBBR) (Tingkat Kesehatan Bank Berdasarkan Risiko) adalah merupakan hasil penilaian atas berbagai aspek yang berpengaruh terhadap kondisi atau kinerja suatu bank. Penilaian terhadap factor factor tersebut dilakukan melalui penilaian secara kuantitatif dan/atau secara kualitatif setelah mempertimbangkan unsur Judgement yang didasarkan atas materialitas dari factor factor penilai, serta pengaruh dari factor lain diluar perusahaan, sperti kondisi perekonomian maupun industry perbankan.

Tingkat Kesehatan suatu bank memiliki arti penting dalam pembentukan kepercayaan masyarakat dimana Bank di tuntut untuk menjaga kesehatannya karena bank yang sehat akan mencerminkan perekonomian yang sehat serta akan berpengaruh terhadap loyalitas nasabah. Tingkat kesehatan bank dapat dinilai dengan menggunakan pendekatan analisis RGEC yaitu dengan menganalisis Risk profile, good Corporate Governance, Earning dan Capital.
Badan Pengelola Keuangan dan Aset Daerah (BPKAD) Kota Jambi dan Kabupaten Tanjung Jabung Barar dalam pengelolaan keuangan daerah yang akuntabel dan transparan sebagaimana diamanatkan dalam Undang-Undang Nomor 32 Tahun 2004 tentang Pemerintahan Daerah sebagaimana telah beberapa kali diubah terakhir dengan Undang-Undang Nomor 9 Tahun 2015 dan Undang-Undang Nomor 33 Tahun 2004 tentang Perimbangan Keuangan antara Pemerintah Pusat dan Pemerintah Daerah, Pemerintah Kabupaten Tanjung Jabung Barat menyusun Laporan Keuangan Pemerintah Daerah (LKPD) sebagai bentuk laporan pertanggungjawaban pelaksanaan APBD. Laporan Keuangan dimaksud disusun sesuai dengan Standar Akuntansi Pemerintahan sebagaimana diatur dalam Peraturan Pemerintah Nomor 71 Tahun 2010 tentang Standar Akuntansi Pemerintahan Berbasis Akrual. Disadari bersama keberhasilan daerah untuk mengurus rumah tangganya sendiri akan dapat berhasil dan berdaya guna apabila aspek perencanaan, pengorganisasian dan pengawasan di bidang pemerintahan dan keuangan saling memberikan umpan balik (LHP TA 2018).

Salah satu faktor penting yang mempengaruhi kesiapan penerapan standar akuntansi pemerintahan berbasis akrual. Kualitas SDM memegang peranan penting dalam sebuah organisasi oleh karena itu pemerintah pusat dan daerah perlu secara serius menyusun perencanaan dan penempatan SDM dibidang akuntansi pemerintahan (Setyaningsih, 2012).

Penelitian sebelumnya tentang sumber daya manusia berpengaruh terhadap kesiapan penerapan SAP berbasis akrual yang dilakukan oleh Jantong (2017) bahwa sumber daya manusia tidak berpengaruh terhadap kesiapan penerapan SAP berbasis akrual. Temuan hasil penelitian ini tidak sejalan dengan penelitian Yahya et.al (2018) yang menyatakan bahwa faktor-faktor yang mempengaruhi penerapan SAP berbasis akrual yaitu sumber daya manusia menunjukkan hasil berpengaruh terhadap kesiapan penerapan SAP berbasis akrual.

Puspitarini (2017) meneliti tentang pengaruh kompetensi sumber daya manusia dan komitmen pimpinan terhadap penerapan akuntansi berbasis akrual pada pengelolaan barang milik Negara. Hasil penelitiannya menunjukkan kompetensi SDM berpengaruh positif terhadap penerapan akuntansi pemerintah berbasis akrual pada pengelolaan barang milik Negara dan komitmen pimpinan berpengaruh positif terhadap penerapan akuntansi pemerintah berbasis akrual pada pengelolaan barang milik Negara.

Ajhar et.al (2015) dalam penelitiannya mengungkapkan bahwa sumber daya manusia berpengaruh terhadap kesiapan penerapan SAP berbasis akrual

Fenomena tersebut menarik peneliti untuk mengkaji dan mengetahui lebih lanjut tentang kesiapan pemerintah daerah dalam menerapkan SAP Berbasis Akrual dengan menggunakan variabel sumber daya manusia, infrastruktur, dan teknologi informasi. Dalam penelitian ini untuk memberikan bukti pengaruh dan untuk membuktikan apakah hasil penelitian selanjutnya 
akan sama atau berbeda dengan penelitian-penelitian sebelumnya apabila dilakukan pada pemerintah daerah yang berbeda dimana BPKAD adalah suatu institusi yang diamanatkan untuk menerapkan SAP Berbasis Akrual dengan tugas mengelola keuangan dan aset daerah.

\subsection{Rumusan Masalah}

Berdasarkan uraian di atas, maka selanjutnya dapat dirumuskan dalam bentuk pertanyaan sebagai berikut:

1. Apakah Risk Profile, Good Corporate Governance, Earning dan Capital berpengaruh terhadap pertumbuhan Laba pada Perusahaan Perbankan yang terdaftar di Bursa Efek Indonesia Periode 20162018 ?

2. Apakah Risk Profile berpengaruh terhadap pertumbuhan Laba pada Perusahaan Perbankan yang terdaftar di Bursa Efek Indonesia Periode 20162018 ?

3. Apakah Good Corporate Governance berpengaruh terhadap Pertumbuhan Laba pada Perusahaan Perbankan yang terdaftar di Bursa Efek Indonesia Periode 2016-2018?

4. Apakah Earning berpengaruh terhadap Pertumbuhan Laba pada Perusahaan Perbankan yang terdaftar di Bursa Efek Indonesia Periode 2016-2018?

5. Apakah Capital berpengaruh terhadap Pertumbuhan Laba pada Perusahaan Perbankan yang terdaftar di Bursa Efek Indonesia Periode 2016-2018?

\subsection{Tujuan Penelitian}

Penelitian ini bertujuan untuk mengetahui:

1. Apakah Risk profile, GCG, Earning dan Capital berpengaruh terhadap pertumbuhan Laba pada Perusahaan Perbankan yang terdaftar di Bursa Efek Indonesia Periode 2016-2018?

2. Apakah Risk profile berpengaruh terhadap pertumbuhan Laba pada Perusahaan Perbankan yang terdaftar di Bursa Efek Indonesia Periode 20162018 ?

3. Apakah GCG berpengaruh terhadap pertumbuhan Laba pada Perusahaan Perbankan yang terdaftar di Bursa Efek Indonesia Periode 2016-2018?

4. Apakah Earning berpengaruh terhadap pertumbuhan Laba pada Perusahaan Perbankan yang terdaftar di Bursa Efek Indonesia Periode 2016-2018?

5. Apakah Capital berpengaruh terhadap pertumbuhan Laba pada Perusahaan Perbankan yang terdaftar di Bursa Efek Indonesia Periode 2016-2018?

\subsection{Manfaat Penelitian}

Manfaat yang penulis harapkan dari hasil penelitian ini antara lain adalah sebagai berikut:

1. Sebagai masukan bagi Bank untuk mengevaluasi RBBR (Tingkat Kesehatan Bank) bagi perusahaan perbankan dengan menggunakan pendekatan RGEC.

2. Sebagai pengetahuan lebih lanjut terkait informasi Tentang RBBR (Tingkat Kesehatan Bank).

\section{KAJIAN PUSTAKA DAN PERUMUSAN HIPOTESIS}

\subsection{Konsep Teori}

\subsubsection{Teori Stewardship}

Menurut Lestari (2013) teori stewardship adalah teori yang menggambarkan situasi di mana para manajer tidaklah termotivasi oleh tujuan-tujuan individu tetapi lebih ditujukan pada sasaran hasil utama mereka untuk kepentingan organisasi.

\subsubsection{Agent of Trust}

Fungsi ini menunjukkan bahwa aktivitas intermediasi yang dilakukan oleh dunia perbankan dilakukan berdasarkan asas kepercayaan, dalam pengertian bahwa kegiatan pengumpulan dana yang dilakukan oleh bank tentu harus didasari rasa percaya dari masyarakat atau dari nasabah.

\subsubsection{Agent of Development}

Fungsi ini berkaitan dengan tanggung jawab bank dalam menunjang kelancaran transaksi ekonomi yang dilakukan oleh setiap pelaku ekonomi. Bank sebagai lembaga keuangan tertentu mempunyai peran yang strategis, sehinggaberfungsi untuk menjembatani dalam transaksi ekonomi yang dilakukan.

\subsection{Risk Based Bank Rating (RBBR)}

Risk Based Bank Rating (Tingkat Kesehatan Bank Berdasarkan Risiko) adalah merupakan hasil penilaian atas berbagai aspek yang berpengaruh terhadap kondisi atau kinerja suatu bank.penilaian terhadap factor factor tersebut dilakukan melalui penilaian secara kuantitatif dan/atau secara kualitatif setelah mempertimbangkan unsur Judgement yang didasarkan atas materialitas dari factor factor penilai, serta pengaruh dari factor lain diluar perusahaan, sperti kondisi perekonomian maupun industry perbankan.

Kesehatan suatu bank memiliki arti penting dalam pembentukan kepercayaan masyarakat dan di tuntut untuk menjaga kesehatannya karena bank yang sehat akan mencerminkan perekonomian yang sehat pula. Pokok pokok pengaturan atau Standar untuk melakukan penilaian kesehatan bank telah ditentukan oleh pemerintah melalui Bank Indonesia yang tertera pada Peraturan Bank Indonesia No.13/1/PBI/2011 dan POJK No 8/POJK.03/2014. Tentang penilaian tingkat kesehatan Bank Umum ,Syariah dan Unit Usaha Syariah. Penilaian tingkat kesehatan bank diperbarui menggunakan metodeRisk-Based Bank Rating (RBBR). Pengukuran tingkat kesehatan bank dengan mengunakan metode pendekatan risiko yang terdiri dari 
empat faktor yaitu profil risiko (risk profile), Good Corporate Governance (GCG), rentabilitas (earnings) dan permodalan (capital).

Berdasarkan uraian di maka hipotesis penelitian sebagai berikut:

H1: Variabel NPL (X1), LDR (X2), Good Corporate Governance (X3), ROA (X4), BOPO (X5) dan CAR (X6) berpengaruh terhadap Pertumbuhan Laba (Y).

H2: Variabel Risk Profile yang diukur dengan Non Performing Loan (NPL) berpengaruh negatif terhadap Pertumbuhan Laba.

H3: Variabel Risk Profile yang diukur dengan Loan to Deposit Ratio (LDR) berpengaruh positif terhadap Pertumbuhan Laba.

H4: Variabel Earnings yang diukur dengan Return On Assets (ROA) berpengaruh positif terhadap Pertumbuhan Laba.

H6: Variabel Earnings yang diukur dengan Biaya Operasional terhadap Pendapatan Operasional (BOPO)berpengaruh negatif terhadap Pertumbuhan Laba.

H6: Variabel Capital yang diukur dengan Capital Adequancy Ratio (CAR) berpengaruh positif terhadap Pertumbuhan Laba.

\section{METODE PENELITIAN}

\subsection{Teknik Pengumpulan Data}

Teknik pengumpulan data yang digunakan dalam penelitian ini yaitu dengan metode dokumentasi. Metode dokumentasi adalah pengumpulan data dengan dokumen yang dapat berupa laporan keuangan yang telah dikumpulkan dan dipublikasikan.

\subsection{Populasi dan Sampel}

Populasi dalam penelitian ini adalah Perusahaan Perbankan yang terdaftar di Bursa Efek Indonesia 20162018. Teknik yang digunakan dalam pengambilan sampel menggunakan metode purposive sampling yaitu metode penentuan sampel dengan pertimbangan tertentu (Sugiyono, 2009) dengan menggunakan karakteristik sebagai berikut:

a. Perusahaan Perbankan yang terdaftar di Bursa Efek Indonesia 2016- 2018.

b. Perusahaan yang menerbitkan laporan keuangannya untuk periode yang berakhir pada 31 Desember, selama periode pangamatan.

Maka dapat diperoleh jumlah sampel sebanyak 36 perusahaan pertambangan yang terdaftar di Bursa Efek Indonesia.

$$
\text { NPL }=\frac{\text { Kredit bermasalah }}{\text { Total Kredit }} \times 100 \%
$$

\subsection{Metode Analisis Data}

Metode analisis yang digunakan dalam penelitian ini adalah regresi linear berganda, yaitu suatu analisis yang digunakan untuk mengetahui pengaruh variabel-variabel independen terhadap variabel dependen. Sebelum analisis regresi dilakukan, terlebih dahulu harus dipenuhi uji normalitas, uji multikolinearitas, uji autokorelasi, dan uji heterokedastisitas.

Model regresi yang dibentuk adalah:

$Y=a+\beta_{1} X_{1}+\beta_{2} X_{2}+\beta_{3} X_{3}+\beta_{4} X_{4}+\beta_{5} X_{5}$

$+\beta_{6} X_{6+}$

$$
\begin{aligned}
& \mathrm{Y}=\text { Pertumbuhan Laba } \\
& \mathrm{X}_{1} \quad=\text { NPL } \\
& \mathrm{X}_{2} \quad=\mathrm{LDR} \\
& \mathrm{X}_{3} \quad=\mathrm{GCG} \\
& \mathrm{X}_{4} \quad=\mathrm{ROA} \\
& \mathrm{X}_{5} \quad=\mathrm{BOPO} \\
& \mathrm{X}_{6} \quad=\mathrm{CAR} \\
& \beta 1, \beta 2, \beta 3, \beta 4,=\text { Koefisien } \\
& \text { a }=\text { Konstanta }
\end{aligned}
$$

\subsection{Definisi Operasional Variabel Penelitian}

\subsubsection{Variabel Dependen}

Variabel dependen yang difokuskan dalam penelitian ini adalah pertumbuhan laba. Laba yang digunakan dalam penelitian ini adalah laba setelah pajak (Earnings After Tax), pertumbuhan laba dapat dirumuskan sebagai berikut (Usman, 2003):

$\Delta \mathrm{Y}=\frac{\text { Yit }- \text { Yit-1 }}{\text { Yit-1 }} \quad \mathrm{X} 100 \%$

Keterangan:

$\Delta \mathrm{Y}_{\mathrm{it}}=$ pertumbuhan laba pada periode $\mathrm{t}$

$\mathrm{Y}_{\text {it }}$ = laba perusahaan $\mathrm{i}$ pada periode $\mathrm{t}$

$\mathrm{Y}_{\mathrm{it}-1}=$ laba perusahaan $\mathrm{i}$ pada periode $\mathrm{t}-1$

\subsubsection{Variabel Independen (X)}

Variabel independen yang dimaksud dalam penelitian ini adalah:

\section{a). Risk Profile}

Profil risiko hanya difokuskan pada 2 risiko dalam penelitian ini yaitu:

1) Risiko Kredit

Untuk mengukur risiko kredit peneliti menggunakan NPL. Rasio ini menunjukan bahwa kemampuan manajemen bank dalam mengelola kredit bermasalah yang diberikan oleh bank. Semakin tinggi rasio ini maka semakin buruk kualitas kredit bank yang menyebabkan jumlah kredit bermasalah semakin besar (Almilia dan Herdiningtyas, 2005). 


\section{2) Risiko Likuiditas}

Rasio likuiditas yang sering digunakan dalam menilai kinerja suatu bank adalah LDR (Loan to Deposit Rasio). Rasio ini untuk menilai likuiditas suatu bank dengan cara membagi jumlah kredit yang diberikan oleh bank terhadap dana pihak ketiga. Semakin tinggi rasio ini, semakin rendahnya kemampuan likuiditas bank yang bersangkutan, sehingga kemungkinan suatu bank dalam kondisi bermasalah akan semakin besar.

\begin{tabular}{|c|c|c|}
\hline \multirow{2}{*}{$\mathrm{LDR}=$} & Total Kredit & \multirow{2}{*}{$\mathrm{x} 100 \%$} \\
\hline & Total dana pihak ketiga & \\
\hline
\end{tabular}

\section{3) Good Corporate Governance (GCG)}

GCG diukur dengan nilai komposit self Assesment GCG, nilai komposit Self Assesment GCG merupakan kategori penilaian terhadap pelaksanaan prinsip prinsip yang berisikan 11 faktor penilaian GCG yang diperoleh Bank dalam penerapan GCG.

\section{b). Earnings/Rentabilitas}

Rasio rentabilitas yang digunakan dalam penelitian ini adalah:

1) Return On Asset (ROA)

Rasio ini digunakan untuk mengukur kemampuan manajemen bank dalam memperoleh keuntungan secara keseluruhan. Semakin besar ROA suatu bank, maka makin besar tingkat keuntungan bank dan semakin baik pula posisi bank dari segi penggunaan aset.

ROA $=\frac{\text { Laba sebelum pajak }}{\text { Total Aset }} \times 100 \%$

2) Biaya Operasional dengan Pendapatan Operasional (BOPO)

Rasio ini digunakan untuk mengukur tingkat efisiensi dan kemampuan bank melakukan kegiatan operasinya. Semakin rendah tingkat rasio BOPO berarti semakin baik kinerja manajemen bank tersebut, karena lebih efisien dalam menggunakan sumber daya yang ada di perusahaan.

$$
\mathrm{BOPO}=\frac{\text { Biaya operasional }}{\text { Pendapatan operasional }} \times 100 \%
$$

\section{c). Capital}

Rasio permodalan yang digunakan dalam penelitian ini adalah Capital Adequacy Ratio (CAR) adalah rasio kewajiban pemenuhan modal minimum yang harus dimiliki oleh bank.

$$
\text { CAR }=\frac{\text { Modal bank }}{\begin{array}{c}
\text { Aktiva Tertimbang Menurut } \\
\text { Risiko (ATMR) }
\end{array}} \times 100 \%
$$

\section{HASIL DAN PEMBAHASAN}

\subsection{Hasil Pengujian Secara Simultan (Uji F)}

Pengujian hipotesis mengenai pengaruh Risk Profile, GCG, Earning, dan Capital menunjukkan nilai signifikansi 0,020 lebih kecil $0,05(5 \%)$ dengan nilai $F_{\text {hitung }}$ lebih besar dibanding $F_{\text {tabel }}(2,636>2,19)$. Hal ini mengindikasikan bahwa $\mathbf{H}_{1}$ diterima yang berarti Risk Profile, GCG, Earning, dan Capital berpengaruh signifikan secara bersama-sama dengan Pertumbuhan Laba.

\subsection{Hasil Pengujian Secara Parsial (Uji t)}

\subsubsection{Pengaruh Risk Profile terhadap Pertumbuhan Laba}

Berdasarkan hasil penelitian pengujian regresi yang diketahui bahwa variabel Risk Profile yang diwakili dengan $N P L$ memiliki nilai $t_{\text {hitung }}$ lebih besar dibanding $t_{\text {tabel }}(\mathbf{3 , 0 2 8}>1,658)$ dengan nilai signifikansi lebih kecil dari $0,05(0,003<0,05)$. Hasil ini menunjukkan bahwa $\mathbf{H}_{2}$ diterima yang berarti bahwa Risk Profile berpengaruh terhadap Pertumbuhan Laba.

Menurut Fikri (2017) kenaikan atau penurunan suatu aset merupakan perubahan yang semu artinya nilai aset perusahaan tidak mampu menggambarkan kondisi financial stability perusahaan dimana setiap perusahaan tidak semuanya mengalami penurunan nilai aset. Hasil penelitian ini menunjukkan berapapun hasil dari perubahan pertumbuhan kredit bermasalah suatu perusahaan tidak mempengaruhi kondisi terhadap kinerja keuangan sehingga menunjukkan bahwa tidak selalu perusahaan yang memiliki tingkat pertumbuhan kredit bermasalah yang tinggi cendrung menghasilkan pertumbuhan laba yang tinggi, karena pertumbuhan kredit bermasalah yang diimbangi dengan tingkat pertumbuhan kredit yang lebih tinggi, investormasih tertarik untuk menanamkan modalnya diperusahaan tersebut, dan juga tidak selalu perusahaan yang memiliki presentase NPL yang rendah tidak mau melakukan investasi pada perusahaan tersebut.

\subsubsection{Pengaruh Risk Profile terhadap Pertumbuhan Laba}

Variabel $L D R$ memiliki nilai $t_{\text {hitung }}$ lebih kecil dibanding $\mathrm{t}_{\text {tabel }}(-0,062<1,658)$ dengan nilai signifikansi lebih kecil dari $0,05(0,951>0,05)$. Hasil ini menunjukkan bahwa $\mathbf{H}_{3}$ diterima yang berarti bahwa LDR tidak berpengaruh terhadap pertumbuhan Laba.

Risiko Likuiditas adalah risiko akibat ketidakmampuan bank memenuhi kewajiban yang telah jatuh tempo dari sumber pendanan arus kas atau dari asset likuid berkualitas tinggi yang dapat diagunkan tanpa mengganggu aktifitas dan kondisi keuangan bank. Perusahaan yang memiliki rasio LDR yang tinggi belum 
tentu perusahaan tersebut dapat meningkatkan pertumbuhan laba jika dibandingkan dengan perusahaan yang memiliki rasio LDR yang rendah.Hal ini diduga karena LDR yang dimiliki oleh bank yang dijadikan sampel penelitian tidak banyak memberikan konstribusi terhadap pertumbuhan laba.

Hasil penelitian ini sejalan dengan penelitian yang dilakukan oleh Tio(2013) dan Fathoni, dkk. (2012) yang menyatakan bahwa LDR tidak berpengaruh signifikan terhadap pertumbuhan laba.Namun penelitian ini tidak sejalan dengan penelitian yang dilakukan oleh Anisah(2013) yang menyatakan bahwa LDR berpengaruh signifikan terhadap pertumbuhan laba.

\subsubsection{Pengaruh GCG terhadap Pertumbuhan Laba}

Berdasarkan hasil penelitian pengujian regresi variabel $G C G$ memiliki nilai $t_{\text {hitung }}$ lebih besar dibanding $\mathrm{t}_{\text {tabel }}(2,689>1,658)$ dengan nilai signifikansi lebih kecil dari $0,05(0,004<0,05)$. Hasil ini menunjukkan bahwa $\mathbf{H}_{4}$ diterima yang berarti bahwa $G C G$ berpengaruh terhadap Pertumbuhan Laba.

Tata kelola Perusahaan yang baik (GCG) pada Perbankan dideskrpsikan sebagai suatu hubungan antara dewan komisaris, dewan Direktur, Stakehoder dan pemegang saham. GCG menciptakan struktur yang membantu Bank dalam menetapkan tujuan, menjalankan operasi harian, mempertimbangkan kepentingan Stakeholder Bank yang beroperasi dengan baik dan sehat, menyesuaikan dengan hukum dan aturan yang berlaku, memproteksi kepentingan nasabah kreditur. Hasil penelitian ini tidak sejalan dengan penelitian Riska Wahyuni (2018) yang menyatakan bahwa GCG berpengaruh negative tidak signifikan terhadap variabel pertumbuhan laba.

\subsubsection{Pengaruh Earning terhadap Pertumbuhan Laba}

Hasil pengujian regresi diketahui bahwa variabel Earning yang diproksikan dengan ROA memiliki nilai $\mathrm{t}_{\text {hitung }}$ lebih besar dibanding $\mathrm{t}_{\text {tabel }}(0,102<1,658)$ dengan nilai signifikansi lebih kecil dari $0,05(0,919>0,05)$. Hasil ini menunjukkan bahwa $\mathbf{H}_{5}$ ditolak yang berarti bahwa Earning ( ROA ) tidak berpengaruh terhadap pertumbuhan Laba.

Menurut Septriani dan Handayani (2018) hasil ROA tahun sebelumnya yang tinggi menunjukkan bahwa perusahaan tersebut memiliki laba yang tinggi dan akan menargetkan perolehan laba yang tinggi diperiode dimasa yang akan datang. Perusahaan perbankan seringkali mendapatkan tekanan yang berlebihan untuk mengupayakan tercapainya laba yang meningkat dari tahun sebelumnya atau minimal sama dengan tahun sebelumnya. Manajemen ditekan untuk mendapatkan jumlah nasabah yang terus bertambah, pendanaan dari nasabah yang harus ditambah atau meningkatnya pengajuan kredit oleh nasabah, karena dengan meningkatnya operasi aktivitas di perusahaan perbankan tersebut, maka secara tidak langsung perusahaan akan mendapatkan laba yang lebih tinggi. dikarenakan pada saat perusahaan memiliki leverage yang tinggi, berarti perusahaan itu memiliki utang yang besar. Utang yang besar itu merupakan sumber tekanan bagi perusahaan karena resiko gagal dalam mengembalikan utang tersebut juga akan semakin tinggi, sehingga akan memunculkan potensi kecurangan dari manajemen, pada saat manajemen ingin meningkatkan pendanaan untuk meningkatkan kinerja keuangan perusahaan, namun perusahaan kesulitan untuk memenuhi persyaratan kredit dan timbul kekhawatiran bahwa pada saat jatuh tempo, perusahaan tidak sanggup untuk mengembalikannya maka akan memberikan peluang untuk manajemen melakukan fraud (Skoesen et al., 2008).

\subsubsection{Pengaruh BOPO terhadap Pertumbuhan Laba}

Berdasarkan hasil penelitian pengujian regresi, diketahui bahwa variabel Earning yang diproksikan dengan BOPO memiliki nilai $t_{\text {hitung }}$ lebih kecil dibanding $\mathrm{t}_{\text {tabel }}(0,875<1,99125)$ dengan nilai signifikansi lebih kecil dari $0,05(0,384>0,05)$. Hasil ini menunjukkan bahwa $\mathbf{H}_{6}$ ditolak yang berarti bahwa $B O P O$ tidak berpengaruh terhadap pertumbuhan Laba.

Suatu perusahaan dalam menjalankan kegiatanya membutuhkan dana untuk operasional, oleh karena itu mereka dituntut untuk dapat mengelola dana tersebut seefisien mungkin sehingga akan meningkatkan laba usaha. Jika bank tidak mampu untuk melakukan efisiensi dalam pengeluaran biaya untuk mendapatkan suatu pendapatan yang tinggi, dan tidak mampu untuk menekan biaya operasional maka akan berpengaruh terhadap pencapaian laba. Disamping hal diatas, adanya kebijakan otoritas Bank Indonesia untuk menurunkan tingkat suku bunga Bank akan berpengaruh terhadap pendapatan bunga bank yang merupakan pendapatan utama Bank dari penyaluran kredit kepada nasabah. Penelitian ini sejalan dengan penelitian Nurul Rafikah (2017) yang menyimpulkan bahwa BOPO tidak berpengaruh terhadap pertumbuhan laba perusahaan perbankan.

\subsubsection{Pengaruh Capital Terhadap Pertumbuhan Laba}

Hasil pengujian regresi diketahui bahwa variabel Capital yang diproksikan dengan CAR memiliki nilai $\mathrm{t}_{\text {hitung }}$ lebih kecil dibanding $\mathrm{t}_{\text {tabel }}(2,241>1,658)$ dengan nilai signifikansi lebih kecil dari $0,05(0,010<0,05)$. Hasil ini menunjukkan bahwa $\mathbf{H}_{7}$ diterima yang berarti bahwa Capital berpengaruh terhadap pertumbuhan Laba.

Bank diharapkan dapat memiliki modal yang cukup dalam upaya untuk melindungi dari risiko yang mungkin timbul dalm menjalankan kegiatan usahanya, kecukupan modal dalam menyerap setiap kemungkinan adanya risk loss yang timbul memberikan rasa aman dalam melaksanakan kegiatan usaha guna menghasilkan laba maksimum bagi bank, sehingga dapat meningkatkan laba dan menghasilkan pertumbuhan laba yang maksimal. Arifin dan syukri ( 2006; 148) rasio CAR adalah rasio yang menunjukan kemampuan bank untuk menutup kemungkinan kerugian dalam aktifitas perkreditan dan perdagangan surat berharga, semakin tinggi CAR semakin besar kemampuan untuk menutup 
kemungkinan risk loss dan kinerja bank akan semakin baik, dan akan meningkatkan pertumbuhan laba.

\subsection{Hasil Uji Koefisien Determinasi $\left(\mathbf{R}^{2}\right)$}

Nilai R-Square sebesar 0,237. Ini berarti bahwa Risk Profile, GCG, Earning, dan Capital hanya dapat mempengaruhi Pertumbuhan Laba sebesar $23.7 \%$ dan sisanya dijelaskan oleh variabel lain di luar model penelitian ini.

\section{SIMPULAN}

\subsection{Simpulan}

Berdasarkan hasil analisis dan pembahasan yang telah diuraikan pada bab sebelumnya, maka dapat diambil simpulan sebagai berikut:

1. Risk Profile, GCG, Earning dan Capital mempunyai pengaruh signifikan secara simultan terhadap Pertumbuhan Laba pada perusahaan Perbankan yang terdaftar di Bursa Efek Indonesia tahun 2016-2018.

2. Risk Profile yang diproksikan dengan NPL berpengaruh negative terhadap Pertumbuhan Laba pada perusahaan Perbankan yang terdaftar di Bursa Efek Indonesia tahun 2016-2018.

3. Risk Profile yang diproksikan dengan LDR tidak berpengaruh terhadap Pertumbuhan Laba pada perusahaan Perbankan yang terdaftar di Bursa Efek Indonesia tahun 2016-2018.

4. Good Corporate Governance (GCG) berpengaruh terhadap Pertumbuhan Laba pada perusahaan Perbankan yang terdaftar di Bursa Efek Indonesia tahun 2016-2018.

5. Earning yang diproksikan dengan ROA tidak berpengaruh terhadap Pertumbuhan Laba pada perusahaan Perbankan yang terdaftar di Bursa Efek Indonesia tahun 2016-2018.

6. Earning yang diproksikan dengan BOPO tidak berpengaruh terhadap Pertumbuhan Laba pada perusahaan perbankan yang terdaftar di Bursa Efek Indonesia tahun 2016-2018.

7. Capital yang diproksikan dengan CAR berpengaruh terhadap Pertumbuhan Laba pada perusahaan Perbankan yang terdaftar di Bursa Efek Indonesia tahun 2016-2018.

\subsection{Saran}

Berdasarkan hasil penelitian, maka peneliti mengajukan beberapa saran perbaikan untuk penelitian dalam memaximalkan pertumbuhan Laba dimasa yang akan datang:

1. Penelitian selanjutnya diharapkan dapat menambah periode pengamatan agar dapat menangkap informasi yang lebih banyak dalam upaya memaximalkan Pertumbuhan laba.
2. Bagi investor dan kreditor diharapkan dapat menjadi salah satu rujukan dalam pengambilan keputusan yang terkait dengan laporan keuangan.

3. Bagi manajemen perusahaan diharapkan dapat digunakan sebagai referensi untuk meningkatkan kinerja Perusahaan.

\section{DAFTAR REFERENSI}

Almilia, Luciana Spica, dan Winny Herdiningtyas, 2005.Analisa Rasio Camel terhadap Prediksi Kondisi Bermasalah padaLembaga Perbankan Periode 2000-2002. Jurnal Akuntansi danKeuangan. Volume 7 Nomor 2, STIE Perbanas, Surabaya, hal 12.

Arifin, Johar \&Muhammad Syukri. 2006. Aplikasi Excel dalam Bisnis Perbankan Terapan. Jakarta: Gramedia

Fathoni, dkk. 2012. Pengaruh Tingkat Kesehatan Bank Terhadap Pertumbuhan Laba Pada Perusahaan Sektor Perbankan. Daya Saing Jurnal Ekonomi Manajemen Sumber Daya (Vol. 13 No. 1, Juni 2012).

Kuncoro, Mudrajad dan Suhardjono. 2011. "Manajemen Perbankan Edisi Kedua”. Yogyakarta : Fakultas Ekonomi dan Bisnis UGM.

Lestari dkk, 2015. Dampak Rasio CAR, NPL, NPM, ROA, IRR, dan Ukuran Perusahaan Dalam Memprediksi Pertumbuhan Laba pada Perusahaan Sektor Perbankan yang Go Public di BEI Periode 2009-2013". Jurnal Ilmiah Akuntansi Universitas Pandanaran. (Vol. 1 No. 1, Febuari 2015. ISSN:2502-7697)

Riska,wahyuni, 2017. Pengaruh, Good Corporate Governance (GCG), Ernings, dan Capital Terhadap Pertumbuhan Laba Perbangkan yang Terdaftar di Bursa Efek Indonesia (BEI) periode 2014-2017. E - Jurnal Riset Manajemen Unisma

Sugiyono, 2013. Metode penelitian Kuantitatif, Kualitatif, dan R\&D. Bandung:Alfabeta

Skousen et al., 2008. Detecting and Predecting Financial Statement Fraud : The Effectiveness of Fraud Triangle and SAS No. 99. In C.J. Skousen, K.R. Smith, \& C.J. Wright, Advances in Financial Economics (pp. 53-81). Bingley: Emerald Group Publishing Limited.

Usman, Bahtiar. 2003. Analisis Rasio Keuangan dalam Memprediksi Perubahan Laba pada Bank - Bank di Indonesia. Media Riset Bisnis dan Manajemen, Volume 3, Nomor 1, hal 59-74. 